\title{
THE USE FLASH CARD TO IMPROVE YOUNG LEARNER'S VOCABULARY MASTERY
}

\author{
Andriyadi $^{1}$, Apep Nana Irawan ${ }^{2}$ \\ ${ }^{1}$ IKIP Siliwangi \\ ${ }^{2}$ IKIP Siliwangi \\ 1andriyadi.axa@gmail.com, ${ }^{2}$ apepirawan9@gmail.com
}

\begin{abstract}
This paper describes the using of flash cards to improve mastery of the vocabulary of young learners. The purpose of this paper is to illustrate the effectiveness and ineffectiveness of flash cards used in teaching vocabulary for young learners. Researchers conducted research using quantitative methods to elementary school children in SDN 2 Cijenuk. The study was conducted in four steps: first planning action, second implementation, and third observation, and last reflection. Data were collected using quantitative data collection techniques. The results showed that the use of Flash cards can improve the mastery of children's vocabulary. This can be seen from the average value of the test that increased from 71.50 on the previous test to 85.55 in the post test. Using a flash card can make students pay attention to the lessons well and not make students bored, also makes the learning atmosphere more controllable.
\end{abstract}

Keywords: Vocabulary Mastery, Flash Card, Young learner

\section{INTRODUCTION}

Learning English is very difficult for us, especially for the level of young learners. Young learners are learner who are ninth until teenth years old who learn English where English is a foreign language.

Moreover we know English is including a unknown language for us. But with the development of the era then the demand to be able to master the world language becomes mandatory, especially for the younger generation of the nation. Can not be denied that learning English is very important. But learning English is not as easy as we think. Especially for young learners who are new to English. One that supports students to learn English is to master the vocabulary in English, by using a flash card one of them.

Flashcards are good method to use for in learning. You can use flash cards to learn almost any lesson for each class and level in school, such as vocabulary, equations and formulas, terms and definitions or key ideas and topics. And much more lessons that can be collaborated with flash cards.

Indonesians will have difficulty using English. Especially for young Indonesian students. It takes $7^{\text {th }}$ years for a student to learn a foreign language until he is proficient in using the language. (Harmer, 1998) argues that the general principle of the past is to teach words that are more real to beginner levels and gradually become more abstract. Words such as "chair", "whiteboard", and others. Can be found in lower level syllabus are things that are represented by real words and appear in front of students and easily explained also understood. 
(Haycraft, 1997) says that at the beginner level, it is better to choose certain words related to the work or profession they are undergoing. Which has been described in the above theories, it can be concluded from the curiosity that the English vocabulary that should be taught to the beginner level is concrete words like things around them as a topic and for the middle level must also be adjusted as well as for the highest level.

English vocabulary to young Indonesian learners is difficult because it differs from the Indonesian vocabulary in terms of pronunciation or writing. Spelling and pronunciation between English and Indonesian is very different. Likewise, one word has more than one meaning and meaning that we do not yet know. In addition, there also has a very different word function in certain sentences that we mean. According to the researchers, ideally elementary students should get the vocabulary material, ie pronunciation, spelling, meaning, and the use of words in gradually mastering vocabulary. Based on four vocabulary indicators, second grade students of SDN 2 Cijenuk have some problems from all indicators.

Problems were found and identified from the observer's observations, and interview results conducted prior to the study. Based on experience made to grade 2 students of SDN 2 Cijenuk, problems encountered by the students are caused by the class situation, the media used by the students and the students themselves.

The condition of the second grade students' class at SDN 2 Cijenuk is monotonous using nonpirated methods. No movement from their seats. It makes them bored and less looking because of the same atmosphere in their class.

Most of them are noisy in the classroom, like moving around in circles and chasing each other, chatting with friends and harassing their friends. Conditions that occur lower their motivation. Therefore, the students are not enthusiastic in learning English. It greatly affects student achievement in learning vocabulary. Of the student factors, most of the second graders at SDN 2 Cijenuk felt that English lessons were difficult.

Difficulty in pronunciation, spelling, memorizing and writing. This condition will get worse because they lack confidence. Based on observations, interviews, researchers proposed to use flashcards in teaching vocabulary. as which is expressed by (Haycraft, 1997), flash cards are cards where words and pictures or drawings are printed and drawn. in size large enough to be clearly visible to all student in the class while studying. He also pointed out that flash cards can be used to convey vocabulary, train structure and word order, or as a game.

Flash cards are a tool in teaching visually. According to what has been suggested by (Brewster, 1992) visual learning is essential to help convey meaning and help students to memorize new words. And also, (Schmitt, 1997) suggesting that new words can be learned with the help of meaningful images, but not definitions.

Means that the flash card is a card that has images or printed with words can also images, meaning not the definition or both. It has an ideal size for all students to see in class and easy to master. Flash cards are used in teaching and learning new words that are hard to learn before. It helps students to learn vocabulary in pronunciation and spelling, understanding meaning, memorizing new words they do not know yet, also training the structure and order of words. In addition, flashcards are very practical and can be made by teachers easily. And can also be taken anywhere and anytime we need. Using a flash card also save you time spent on drawing teachers on the board. These can be stored and reused in for all ages. 
Based on the following background, the problems in this study are as follows: "Can and to what extent use of flash cards improve the vocabulary of students in second grade SDN 2 Cijenuk?"

\section{METHOD}

Researchers use quantitative research design, quantitative research design is a research process based on deductive theory that focuses primarily on testing theory and certain research hypotheses which consider finding differences and relationships using numerical data and statistical methods to make specific conclusions about the phenomenon (Kaswan, 2016).

Researchers use pre-experimental designs, with one group pretest and posttest. In experimental method are one group, one case shot study design and one group pretest-posttest design. The first is pretest measuring the dependent variable. The second is application of treatment to the subject and the final step is the administration of posttest measuring dependent variable again.(Kaswan, 2017).

The population is a group of entities or persons in which the results of the study are intended to be applied or applied to the population. The population selected varies according to the research question. In this case, the research could be students, teachers, textbooks, novels, etc. (Kaswan, 2016). Based on assumption above, the researcher took the population its research is classes of SDN 2 Cijenuk that consist of one class. Class 2 each has 20 students.

The instruments used by the researchers are lesson plan with 20 vocabulary questions using the image media to pretest and posttest, so that researchers get some data about the increase of student vocabulary mastery.

First the researchers gave the pretest about the vocabulary to get data of the extent to which students' mastery of the vocabulary. Then the researchers provide treatment to the experiment class.

After the researcher gives the treatment to the experiment class the next step is to give posttest to the class, so that got result from the use of flash card media to mastery vocabulary of young learner.

\section{RESULTS AND DISCUSSION}

\section{Results}

Below is presented data which have result of writer research about usage of flash card to increase young learner's vocabulary mastery.

Table 1 Data score of pretest posttest:

\begin{tabular}{|c|c|c|c|}
\hline NO & STUDENT & PRITEST & POSTTEST \\
\hline 1 & $\mathrm{a} 1$ & 74 & 88 \\
\hline 2 & $\mathrm{a} 2$ & 72 & 87 \\
\hline 3 & $\mathrm{a} 3$ & 74 & 87 \\
\hline 4 & $\mathrm{a} 4$ & 74 & 86 \\
\hline 5 & $\mathrm{a} 5$ & 86 & 87 \\
\hline 6 & $\mathrm{a} 6$ & 80 & 91 \\
\hline
\end{tabular}




\begin{tabular}{|c|c|c|c|}
7 & $\mathrm{a} 7$ & 70 & 88 \\
\hline 8 & $\mathrm{a} 8$ & 66 & 78 \\
\hline 9 & $\mathrm{a} 9$ & 68 & 87 \\
\hline 10 & $\mathrm{a} 10$ & 68 & 88 \\
\hline 11 & $\mathrm{a} 11$ & 66 & 86 \\
\hline 12 & $\mathrm{a} 12$ & 68 & 87 \\
\hline 13 & $\mathrm{a} 13$ & 82 & 92 \\
\hline 14 & $\mathrm{a} 14$ & 64 & 78 \\
\hline 15 & $\mathrm{a} 15$ & 68 & 83 \\
\hline 16 & $\mathrm{a} 16$ & 66 & 78 \\
\hline 17 & $\mathrm{a} 17$ & 74 & 87 \\
\hline 18 & $\mathrm{a} 18$ & 70 & 85 \\
\hline 19 & $\mathrm{a} 19$ & 68 & 82 \\
\hline 20 & $\mathrm{a} 20$ & 70 & 86 \\
\hline
\end{tabular}

Table 2 Tests of Normality

\begin{tabular}{|l|r|r|r|r|r|r|}
\hline & \multicolumn{4}{|c|}{ Kolmogorov-Smirnov ${ }^{\mathrm{a}}$} & \multicolumn{3}{c|}{ Shapiro-Wilk } \\
\cline { 2 - 7 } & Statistic & \multicolumn{1}{c|}{$\mathrm{df}$} & \multicolumn{1}{c|}{ Sig. } & Statistic & \multicolumn{1}{c|}{$\mathrm{df}$} & \multicolumn{1}{c|}{ Sig. } \\
\hline Pritest & .196 & 20 & .043 & .880 & 20 & .018 \\
Posttest & .246 & 20 & .003 & .868 & 20 & .011 \\
\hline
\end{tabular}

The result test of normality is :

Pretest : sig. 0,363 $>0,005=$ Sample are normally distributed

Posttest : sig. 0,011 $>0,005=$ sample are normally distributed

T Test

Table 3 Paired Samples Statistics

\begin{tabular}{|c|c|c|c|c|c|}
\hline & & Mean & $\mathrm{N}$ & Std. Deviation & Std. Error Mean \\
\hline & Pritest & 71.40 & 20 & 5.771 & 1.290 \\
\hline Pair 1 & Posttest & 85.55 & 20 & 3.927 & .878 \\
\hline
\end{tabular}

Table 4 Paired Samples Correlations

\begin{tabular}{|lc|r|r|r|}
\hline & \multicolumn{1}{|c|}{$\mathrm{N}$} & Correlation & \multicolumn{1}{c|}{ Sig. } \\
\hline Pair 1 & Pritest \& Posttest & 20 & .666 & .001 \\
\hline
\end{tabular}


Table 5 Paired Samples Test

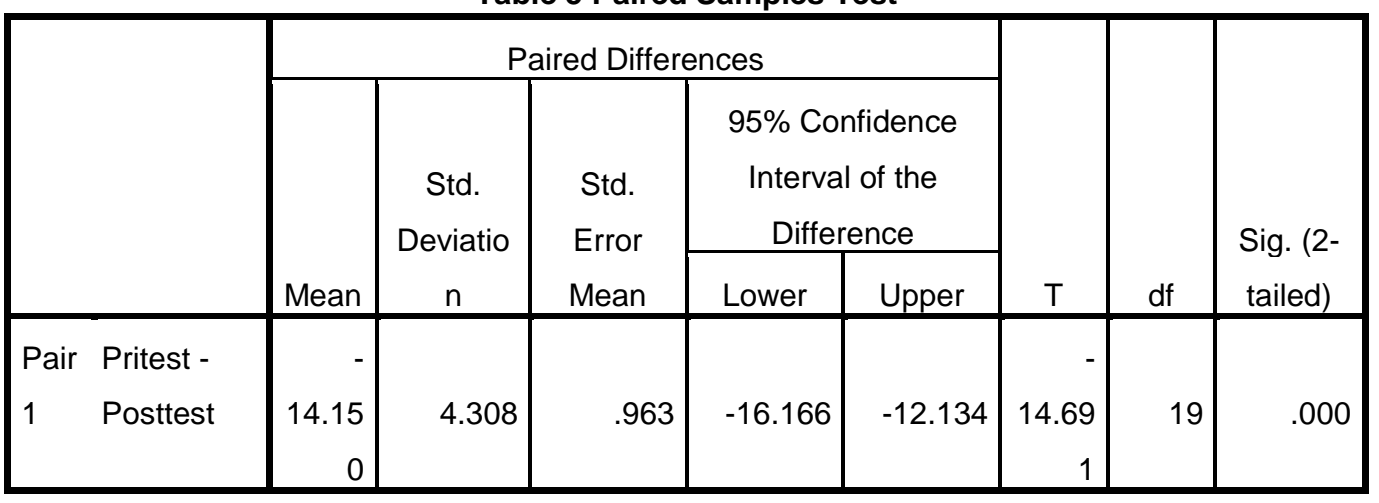

The result of the above parametric test is $0.000<0.005$, so it can be ascertained that $\mathrm{H} 0$ is rejected. With using of Flash Card can improve young learner's vocabulary mastery at SDN Cijenuk 2.

\section{Discussion}

The mean value of the results of the research we can know in the Paired Samples Statistics table above, for pretest is 71.40 , while the mean value after treatment is given to the student or in the next test that is the posttest is 85.55 .

We can also see in the Paired Samples Test table in the sig column. (2-tailed) contains a value of 0.000 which indicates that $\mathrm{H} 0$ is rejected and $\mathrm{H} 1$ accepted so show the method of flash card can improve young learner's vocabulary mastery.

\section{CONCLUSION}

Based on the finding, it can be concluded that the using of flash card media in young learners instruction is influenced towards increasing the improvement of young learner's ability in mastering English vocabulary.

So the study shows that the using of flash card media is better and recommended to use in teaching learning froces.

\section{ACKNOWLEDGMENTS}

First I want to thank Allah SWT for all the help that has been given to me. I would like to thank my supervisor, Iman Santoso S.Pd., M. Hum. for his never-ending guidance so I can work on this article.

I would also like to thank my parents and friends who helped me a lot in completing this article. hopefully, this article can be a useful and proud thing for me and all related parties.

\section{REFERENCES}

Brewster, J. (1992). The Primary English teacher's Guide. London: Penguin Books Ltd. Harmer, J. (1998). The Practice of English Language Teaching. New York: Longman Group UK Limited.

Haycraft, J. (1997). An Introduction to English Language Teaching (Essex: Add). Wesley 


\section{Volume 1, No. 5, September 2018 pp $518-523$}

Longman Limited.

Kaswan. (2017). Metode dan Teknik Penulisan Karya Ilmiah. Bandung: Program Pendidikan Bahasa Inggris STKIP Siliwangi Bandung.

Kaswan, D. suprijadi. (2016). Research in English Language Education. Bandung: Putra Praktisi, Bandung.

Schmitt, N. (1997). Vocabulary: Description, Acquisition and Pedagogy. Cambridge: Cambridge University Press. 